\title{
Pengembangan Video Pembelajaran Sains Berbasis Problem Based Learning
}

\author{
Esty Styowati1, Febriyanti Utami ${ }^{\circledR}$ \\ Pendidikan Guru Pendidikan Anak Usia Dini, Universitas Sriwijaya, Indosensia ${ }^{1}$ \\ DOI: $10.31004 /$ obsesi.v6i4.1970
}

\begin{abstract}
Abstrak
Pada masa pandemi Covid-19 saat ini aktivitas pembelajaran dalam pengenalan sains yang diberikan guru pada anak masih belum bervariasi, sehingga membuat anak mudah bosan sehingga anak kurang memahami tentang pembelajaran sains tersebut. Penelitian ini bertujuan untuk mengembangkan video pembelajaran sains berbasis problem based learning. Subjek penelitian adalah anak usia dini di Desa Nusa Tenggara, Kec. Belitang III, Kab. OKU Timur. Penelitian ini dilakukan menggunakan Model Rowntree dengan tiga tahapan yaitu perencanaan, pengembangan dan evaluasi. Teknik pengumpulan data dilakukan melalui, wawancara, angket, dan observasi. Teknik analisis data yang digunakan dalam penelitian ini yaitu teknik analisis kualitatif dan kuantitatif. Hasil penelitian menunjukkan bahwa pengembangan video pembelajaran sains berbasis problem based learning dinyatakan valid berdasarkan penalian ahli materi dan ahli media. Begitu pula dengan video pembelajaran sains berbasis problem based learning juga dinyatakan praktis berdasarkan penilaian pada tahap one to one evaluation dan small group evaluation.
\end{abstract}

Kata-kata Kunci : video aktivitas sains; problem based learning; anak usia dini

\begin{abstract}
During the current Covid-19 pandemic, learning activities in the introduction of science given by teachers to children are still not varied, thus making children easily bored so that children do not understand about science learning. This study aims to develop a science learning video based on problem based learning. The research subjects were early childhood in Nusa Tenggara Village, Belitang III District, East OKU egency. This research was conducted using the Rowntree Model with three stages, namely planning, development and evaluation. Data collection techniques were carried out through interviews, questionnaires, and observations. Data analysis techniques used in this research are qualitative and quantitative analysis techniques. The results showed that the development of science learning videos based on problem based learning was declared valid based on the correlation of material experts and media experts. The problem-based learning science learning video was also declared practical based on the assessment at the one to one evaluation and small group evaluation stages.
\end{abstract}

Keywords: science activity videos; problem based learning; early childhood

Copyright (c) 2022 Esty Styowati, Febriyanti Utami.

$\triangle$ Corresponding author :

Email Address : febriyantiutami@fkip.unsri.ac.id (Sumatera Selatan, Indonesia)

Received 18 November 2021, Accepted 15 December 2021, Published 19 January 2022 


\section{PENDAHULUAN}

Salah satu aspek perkembangan kognitif yang harus dikembangkan pada anak usia dini yaitu sains. Wenham yang dikutip oleh Gross (2012) mengemukakan bahwa sains adalah cara mengeksplorasi dan menyelidiki dunia di sekitar kita. Sains merupakan suatu pengetahuan yang diperoleh lewat keterampilan kombinasi antara satu dengan lainya yang tumbuh sebagai hasil percobaan atau eksperimen dan pengamatan gejala alam dan fakta-fakta alam yang ada disekitar anak guna mengungkapkan segala sesuatu yang berkaitan dengan alam semesta. Pembelajaran sains, termasuk pengenalan konsep kealaman bagi anak merupakan suatu upaya membantu anak untuk menemukan konsep dan proses tertentu dalam kehidupan, dengan kata lain pembelajaran sains bagi anak pada hakikatnya dijadikan sebagai media yang digunakan untuk menstimulasi aspek perkembangan dan memaksimalkan potensi yang ada dalam diri anak.

Namun pada umumnya, pembelajaran sains di pendidikan anak usia dini masih berupa pengenalan konsep dan hafalan yang terbatas pada sains produk dan belum sampai pada pengenalan sains proses (Dewi, 2012). Pada masa pandemi Covid-19 saat ini, pengenalan atau pengembangan sains yang diberikan guru pada anak biasanya menggunakan metode bercerita dan menggunakan media biasanya seperti kartu gambar sehingga anak mudah bosan sehingga mengakibatkan anak kurang memahami tentang pembelajaran sains tersebut. Seperti halnya yang diungkapkan oleh (Utami, 2020) penggunaan media oleh guru masih minim dalam proses pembelajaran sains di kelas.

Media pembelajaran merupakan alat bantu dalam pembelajaran yang dapat membantu anak untuk mengeksplorasi pengetahuan mereka (Padilah et al., 2018). Maka dari itu media pembelajaran memiliki peranan penting dalam pembelajaran sains. Mengenalkan sains pada anak usia dini dengan cara yang sesuai, dapat mendukung eksplorasi sensorik anak tentang dunia mereka dan dapat memberikan pengetahuan serta keterampilan dasar untuk pembelajaran sains. Salah satunya dengan menggunakan media pembelajaran (Trundle, 2015).

Menurut Aditian et al. (2015), media pembelajaran adalah suatu alat yang secara fisik digunakan untuk menyampaikan suatu informasi atau isi materi pembelajaran yang terdiri dari buku, tape recorder, kaset, video kamera, video recorder, film, slide, foto, gambar, grafik, televisi dan komputer. Media pembelajaran juga merupakan perantara yang dapat digunakan untuk menstimulasi aspek perkembangan anak, salah satunya aspek kognitif yang di dalamnya memuat pembelajaran sains. Media yang dapat digunakan dalam pembelajaran sains yaitu media video yang merupakan salah satu media pengajaran hasil teknologi informasi dan komunikasi yang dapat diperbaiki untuk membatu anak dalam meningkatkan minat belajar anak. Media video ini pada umumnya banyak disenangi oleh anak-anak, karena karakter gambar yang menarik. Dalam menyediakan media pembelajaran di zaman yang semakin canggih ini, orang tua atau guru dapat melihat referensi kegiatan belajar khususnya pembelajaran sains dapat di akses melalui internet seperti youtube, dan lain-lain.

Selain itu, untuk pengenalan sains pada anak usia dini lebih efektif jika menggunakan model pembelajaran yang tepat. Selain anak dapat mengetahui konsep sains, pembelajaran sains dapat difokuskan pada keterampilan proses sains bukan sekedar mendapatkan pengetahuan formal dan perubahan konseptual (Dejonckheere et al., 2016). Salah satu model pembelajaran yang dapat digunakan dalam pembelajaran sains anak usia dini yaitu problem based learning. Menurut Utrifani dan Betty dikutip Rerung et al. (2017), Problem Based Learning (PBL) adalah model pembelajaran yang melibatkan anak untuk memecahkan suatu masalah melalui tahap metode ilmiah sehingga anak dapat mempelajari pengetahuan yang berhubungan dengan masalah tersebut serta memiliki keterampilan untuk memecahkan masalah. Problem based learning adalah pembelajaran yang dirancang untuk mendukung perkembangan anak pada kompetensi kognitif dan sosial (Moallem et al., 2019).

Pada model problem based learning guru berperan sebagai fasilitator dan membimbing proses pembelajaran menggunakan pertanyaan-pertanyaan terbuka sehingga dapat 
menstimulasi kemampuan berpikir pada anak (Wulandari \& Suparno, 2020). Peran guru sebagai fasilitator juga membantu peserta didik untuk membangun pemahaman dan menghubungkan konsep dengan memberikan informasi, mengarahkan anak untuk mengekplorasi, dan memperkuat pemahaman pada konsep yang dianggap sulit (Seibert, 2021). Model pembelajaran ini diterapan pada anak usia dini mengikat karakteristik anak yang sifatnya mempunyai rasa ingin tahu yang tinggi, suka mencoba (trial and error), senang dan kaya akan fantasi. Model Problem Based Learning ini diterapkan pada aktivitas sains, dimana terdapat suatu permasalahan yang nantinya akan dipecahkan melalui suatu kegiatan eksperimen. Di dalam suatu kegiatan eksperimen, anak dapat mudah dalam menemukan solusi atau memecahkan masalah yang dihadapinya dan juga anak dapat menemukan sesuatu yang baru atau bermanfaat dalam kegiatan tersebut.

Melihat pentingnya penggunaan media dan model pembelajaran yang telah diuraikan sebelumnya untuk mengenalkan sains pada anak usia dini, peneliti mencoba untuk mengembangkan produk media pembelajaran berupa video yang nantinya dapat digunakan untuk mengenalkan sains pada anak dan memuat model problem based learning. Pada tahap awal, peneliti melakukan observasi secara langsung dan menganalisis media pembelajaran berupa video yang memuat pembelajaran sains yang ada di YouTube. Hasil pengamatan menyatakan bahwa masih kurangnya ketersediaan video pembelajaran yang menjelaskan secara khusus tentang pembelajaran sains seperti ledakan warna susu ajaib di channel YouTube Indonesia melainkan banyak dijumpai di channel YouTube dari luar negeri yang menggunakan bahasa asing.

Selain itu peneliti melakukan analisis kebutuhan dengan mewawancarai tiga orang tua yang memiliki anak usia 5-6 tahun mengenai pengenalan pembelajaran sains pada saat belajar daring. Hasil dari ketiga wawancara tersebut, cara yang digunakan oleh orang tua dalam mengenalkan sains pada anak cukup beragam yaitu dengan cara menggunakan poster dan buku panduan. Cara yang digunakan orang tua masih sangat sederhana, sehingga belum dikatakan dapat memfasilitasi pembelajaran sains yang sesuai dengan tahapan perkembangan anak. Selanjutnya peneliti menawarkan alternatif media pembelajaran berupa video yang dapat digunakan oleh orang tua untuk mengenalkan pembelajaran sains kepada anak. Hal tersebut mendapat tanggapan positif dari para orang tua. Para orang tua menyatakan bahwa memang memerlukan video tersebut karena pembelajaran melalui video lebih efektif dan menarik perhatian anak untuk belajar. Sejalan dengan hasil penelitian yang dilakukan oleh, bahwa video pembelajaran yang sesuai dengan tujuan pembelajaran pada anak usia dini dapat berguna dan efektif dalam mengenalkan pengetahuan dasar bagi anak usia dini (Yaqoob et al., 2018). Selain itu juga, video pembelajaran dapat memfasilitasi pembelajaran daring pada anak usia dini di masa pandemi Covid-19 saat ini (Syafi'i et al., 2020).

\section{METODOLOGI}

Jenis penelitian yang digunakan adalah penelitian pengembangan atau $\mathrm{RnD}$ (Research and Developmen). Model pengembangan yang digunakan adalah Rowntree dan dimodifikasi dengan evaluasi formatif Tessmer, dengan tiga tahapan yaitu perencanaan, pengembangan dan evaluasi yang ditunjukkan pada gambar 1.

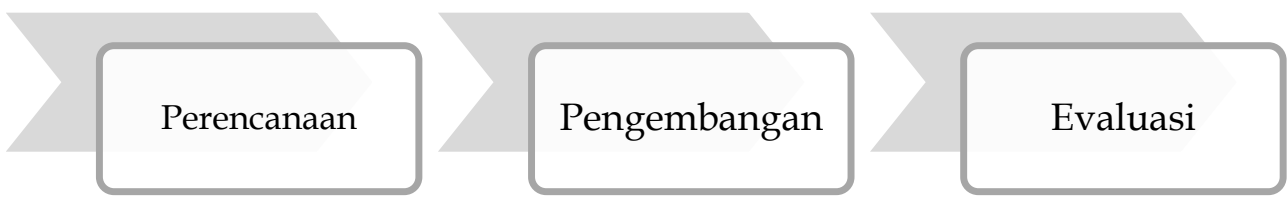

Gambar 1. Tahapan Penelitian Pengembangan Model Rowntree 


\section{Perencanaan}

Pada tahap ini peneliti melakan analisis kebutuhan dengan melihat tingkat pencapaian perkembangan kognitif anak usia 5-6 tahun di Permendikbud No. 137, menganalisis video yang ada serta mewawancarai orang tua yang memiliki anak berusia 5-6 tahun di Desa Nusa Tenggara, Kec. Belitang III, Kab. Oku Timur. Setelah melakukan analisis kebutuhan serta melihat tingkat pencapaian anak, peneliti mendeskripsikan kriteria video yang sesuai dengan kebutuhan masyarakat.

\section{Pengembangan \\ Pengembangan Desain}

Pengembangan desain merupakan penentuan desain produk pada media yang akan dikembangkan yang berupa video. Dalam pengembangan desain produk setelah mendapatkan ide produk yang akan dikembangkan, maka ada beberapa langkah dalam pembuatan video pembelajaran yang harus diperhatikan seperti yang ditunjukkan pada gambar 2 yaitu: 1) tulis skenario yang berfungsi sebagai pemandu ke mana arah pembicara ketika di rekam nanti, 2) proses rekam, 3) cari ilustrasi seperti animasi, gambar dan lainlain, 4) proses editing, 5) proses unggah/upload yang nantinya akan di unggal di situs web seperti youtube. Desain dibuat dengan bantuan menggunakan perangkat lunak yang didalamnya mempunyai banyak bentuk animasi dan nantinya dengan menggunakan animasi tersebut akan dibuat sekreatif dan semenarik mungkin sesuai dengan kebutuhan anak yaitu dengan membuat konsep tentang aktivitas sains.

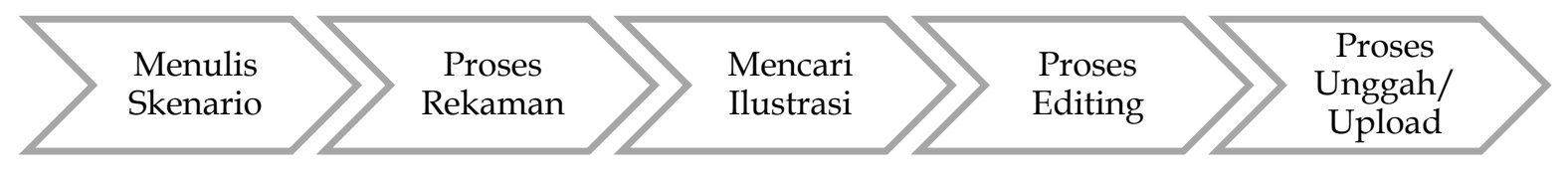

\section{Gambar 2. Bagan Alur Pengembangan Desain Produk}

\section{Produksi Prototipe}

Setelah membuat desain produk, tahap selanjutnya adalah memproduksi prototipe. Produk yang didesain untuk dibuat menjadi media pembelajaran yang tujuanya yaitu agar anak dapat mendapatkan media baru dalam pembelajaran sains. Desain produk sesuai dengan kebutuhan anak dan target yang akan dicapai oleh peneliti adalah penguasaan pemahaman dalam menggunakan media video yang sudah di desain yang berisi pembelajaran aktivitas sains pada anak usia 5-6 tahun. Hasil dari keseluruhan tahap pengembangan ini disebut prototipe 1.

\section{Evaluasi}

Pada tahap ini, prototipe 1 hasil desain awal akan dievaluasi dengan mengikuti prosedur evaluasi formatif dan tessmer dengan langkah-langkah sebagai berikut; Self Evaluation, untuk proses ini penilaian dilakukan oleh peneliti sendiri terhadap media video yang dikembangkan, apakah media sudah sesuai dan tidak berbahaya bagi anak, apakah warnanya menarik, dan apakah anak dapat memahami media video dalam pembelajaran aktivitas sains tersebut dengan mudah. Expert Review, hasil dari produk (prototipe 1) yang akan dikembangkan atas dasar self evaluation, diberikan kepada ahli untuk di validasi. Pada tahap ini validator melihat dan mengevaluasi desain produk yang telah dibuat. Uji validitas yang dilakukan adalah uji validitas content dan desain media video. Hasil validasi yang berupa tanggapan atau komentar dan saransaran pada lembar validasi yang akan dijadikan dasar untuk merevisi media video dalam aktivitas sains pada anak usia 5-6 tahun. One -to-one evaluation (uji coba satu-satu), pada tahap ini, produk media video diujicobakan kepada anak. Peneliti memilih tiga orang anak secara acak untuk mewakili populasi target yaitu anak dengan kemampuan rendah, sedang, dan tinggi. Anak akan diberikan video pembelajaran dengan prototipe 1 yang telah direvisi. Pada saat proses 
pembelajaran, anak akan diamati menggunakan lembar observasi yang sudah di sediakan untuk melihat dan menilai tingkah laku atau proses terjadinya suatu pembelajaran secara langsung dengan menggunakan prototipe 1 . Hal ini dilakukan dengan tujuan untuk melihat kepraktisan media video dari sudut pandang anak. hasil observasi anak tersebut akan dijadikan dasar untuk merevisi produk prototipe 1 sehingga menghasilkan prototipe 2. Small Group Evaluation (uji coba kelompok kecil), pada tahap small group evaluation ini, produk media video ini saling mulai diujicobakan pada anak. peneliti memilih 6 orang anak secara acak untuk mewakili populasi target yaitu anak dengan kemampuan rendah, sedang, dan tinggi. Pada saat proses pembelajaran, anak akan diamati dengan menggunakan lembar observasi yang sudah digunakan untuk menilai serta terlihat tingkah laku atau proses terjadinya suatu pembelajaran secara langsung dengan menggunakan prototipe 2 . Hal ini dilakukan bertujuan untuk melihat kepraktisan media video dalam pembelajaran aktivitas sains.

Dalam penelitian ini tidak menggunakan tahap field test karena penelitian ini hanya sampai pada tahap small group yaitu untuk menguji kevalidan dan kepraktisan suatu produk, bukan untuk menguji keefektifan potensial suatu produk. Cahyati et al. (2018) mengungkapkan bahwa untuk menguji kevalidan dan kepraktisan hanya sampai pada tahap small group evaluation. Tahap field test digunakan untuk menguji efek potensial dalam suatu produk. Masing-masing dari empat tahap ini memiliki hasil yang berbeda-beda sehingga sangat memungkinkan jika hasil teknik evaluasi ini digunakan dalam rangka untuk merevisi suatu prototipe tersebut. Penilaian dari setiap teknik yang dijadikan dasar untuk merevisi prototipe akan memberikan hasil yang berbeda-beda sehingga berguna untuk memperbaiki prototipe yang menjadi produk yang valid dan praktis.

Dalam penelitian ini digunakan beberapa teknik dalam mengumpulkan data yaitu adalah sebagai berikut. 1) Observasi yang dilakukan pada peneliti ini menggunakan lembar ceklis yang dilakukan untuk mengevaluasi produk awal atau prototipe 1 dan selanjutnya dengan memvalidasi data yang menggunakan metode walkthrough oleh para ahli materi dan media. Data yang dikumpulkan dari lembar ceklis yaitu tanggapan, saran serta komentar yang ditulis pada lembar validasi sebagai dasar penelitian untuk merevisi produk. Data hasil validasi dikaji untuk mendapatkan kejelasan informasi mengeni produk sebagai panduan untuk merevisi produk sampai dinyatakan layak untuk diuji cobakan. Teknik observasi dilakukan pada saat one to one evaluation dan small group evaluation. Hasil observasi dicatat pada lembar observasi yang berisi kisikisi untuk mengukur tingkat pencampaian perkembangan anak. 2) Wawancara dilakukan kepada tiga orang tua yang memiliki anak usia 5-6 tahun di desa Nusa Tenggara, Kecamatan Belitang III, Kabupaten Oku Timur.

Pada penelitian ini teknik analisis data menggunakan nilai dan peresentase pada setiap instrumen. Teknik analisis data penelitian ini menggunakan Analisis Data Lembar Checklis yaitu analisis lembar ceklis bertujuan untuk menilai kevaidan video aktivitas sains. Masukan tersebut dituliskan pada lembar validasi. Lembar validasi yang diberikan kepada ahli dalam bentuk skala likert. Menurut Sugiyono, (2019: 94) skala likert digunakan untuk mengukur pendapat,sikap dan tanggapan seseorang atau sekelompok orang tentang fenomena sosial. Dalam penelitian fenomena sosial ini telah ditetapkan secara spesifik oleh peneliti. Skala likert menggunakan 4 kategori jawaban yaitu : sangat baik(SB), baik(B), tidak baik (TB), dan sangat tidak baik (STB) (Modifikasi Skala Likert oleh Sugiyono, 2019 : 93); Analisis Data Observasi yaitu observasi terhadap anak selama uji coba pada tahap one-to one evaluation dan small group evaluation digunakan untuk melihat tingkah laku anak pada saat proses pembelajaran menggunakan media video pembelajaran aktivitas sains berbasis problem based learning. Data hasil observasi disajikan dalam bentuk tabel, kemudian menghitung nilai hasil observasi dengan menggunakan rumus 1, sedangkan nilai observasi dikonversikan ke dalam kategori yang seperti pada tabel 1 . 
Nilai Persentase $=\sum \frac{\text { Skor Perolehan }}{\text { Skor Maksimal }} \times 100 \%$

Rumus 1. nilai hasil observasi

Tabel 1. Kategori Tingkat Praktis Penggunaan Produk

\begin{tabular}{cc}
\hline Rata-Rata & Kategori \\
\hline 4 & BSB \\
3 & BSH \\
2 & MB \\
1 & B \\
\hline \multicolumn{2}{c}{ (Modifikasi Sugiyono, 2019: 99) }
\end{tabular}

\section{HASIL DAN PEMBAHASAN}

Berdasarkan hasil observasi, analisis kebutuhan dan perkembangan anak di Desa Nusa Tenggara, Kec. Belitang III, Kab. Oku Timur diperoleh sebuah permasalahan yaitu kurangnya pemanfaatan teknologi informasi yang digunakan dalam kegiatan pembelajaran dan pada saat pembelajaran daring dimasa pandemi Covid-19, dalam pengenalan atau pengembangan sains pada anak biasanya hanya menggunakan metode bercerita dan hanya menggunakan media seperti poster, sehingga anak mudah bosan sehingga mengakibatkan anak kurang memahami tentang pembelajaran sains tersebut. Padahal penggunaan video dalam proses pembelajaran dapat menarik minat anak dalam belajar.

Pada tahap self evaluation, untuk proses penilaian ini dilakukan oleh peneliti sendiri terhadap media video yang dikembangkan, apakah media sudah sesuai dan tidak berbahaya bagi anak, apakah warnanya menarik, dan apakah anak dapat memahami media video dalam pembelajaran aktivitas sains tersebut dengan mudah. Hasil dari tahap self evaluation ini menunjukkan bawah video pembelajaran sesuai dengan karakteristik anak usia 5-6 tahun dan video pembelajaran memiliki daya tarik bagi anak karena perpaduan gambar dan warna yang serasi serta aman dan mudah dipahami. Adapun hasil dari self evaluasion yang pertama yaitu, pada bagian pembukaan kata sapaan dituliskan dengan teks. Selanjutnya peneliti melakukan perubahan dengan tidak langsung menampilkan teks sapaan saat guru menjelasakan. Tampilan perubahan pada bagian pembukaan dapat dilihat pada gambar 3 .
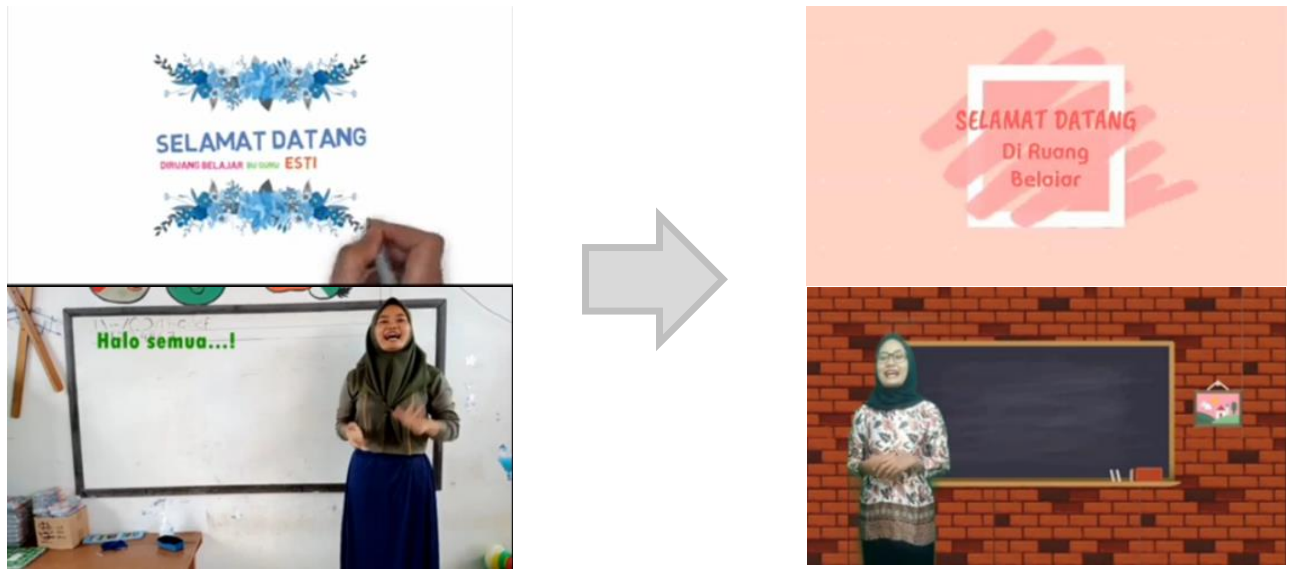

\section{Gambar 3. Perubahan Pada Bagian Pembukaan Video}

Selanjutnya pada bagian inti video, peneliti menambahkan tampilan penjelasan tentang tujuan pembelajaran. Peneliti juga menambahkan penjelasan tentang alat dan bahan, mengenalkan alat dan bahan yang akan digunakan dalam kegiatan pencampuran warna. Pada bagian mengenalkan jenis-jenis warna pada video sebelumnya, peneliti melakukan 
perubahan dengan menambahkan pertanyaan terkait dengan pembelajaran sains yang akan dilakukan dan diharapkan dapat mendorong anak untuk melakukan problem based learning. Selain itu juga, peneliti melakukan perbaikan dengan menambahan pejelasan jumlah takaran warna yang akan digunakan. Tampilan perubahan dapat dilihat pada gambar 4 .
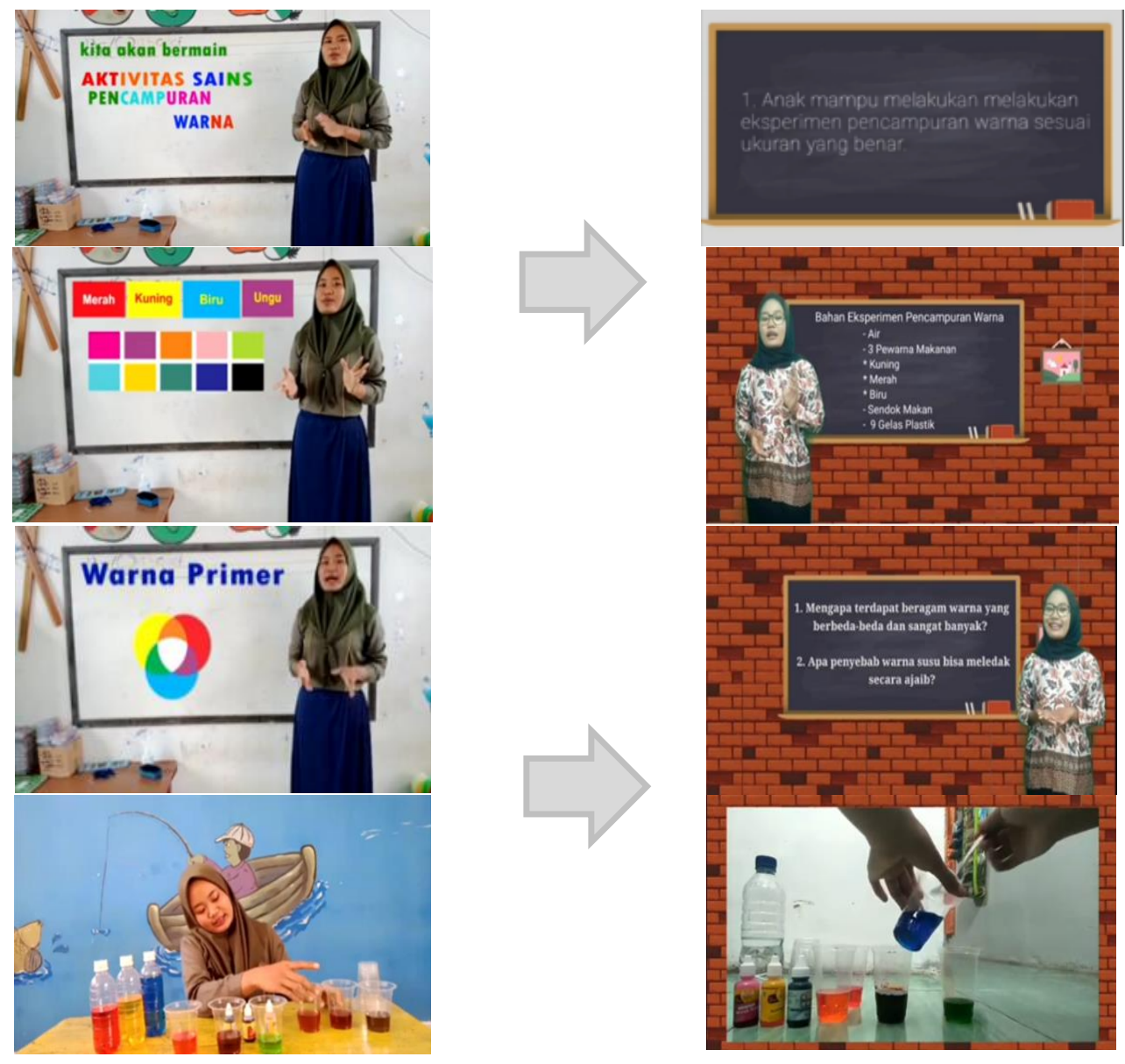

\section{Gambar 4. Perubahan Pada Bagian Inti Video}

Pada bagian penutup peneliti menambahkan kesimpulan dari pembelajaran sains yang sudah dilakukan. Tampilan perubahan pada bagian ini dapat dilihat pada gambar 5 .
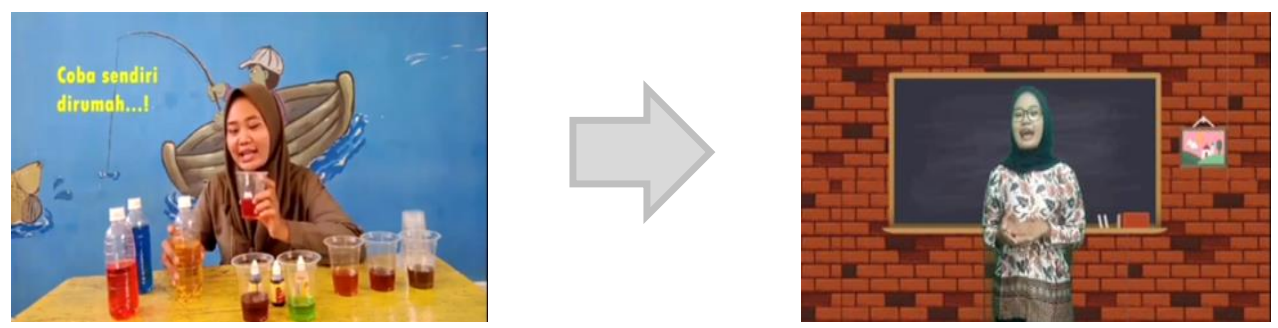

Gambar 5. Perubahan Pada Bagian Penutup Video

Tahap expert review bertujuan untuk mendapatkan nilai dan ahli media dan ahli materi yang teruji validitasnya. Dalam hal ini melibatkan dua orang ahli yaitu ahli media dan ahli materi. Validator untuk ahli media adalah Mahyumi Rantina, M.Pd. dan ahli materi adalah Dr. Windi Dwi Andika, M.Pd. Dari hasil validasi oleh ahli media mendapatakan rata-rata sebesar $80 \%$ dengan kategori valid. Pada hasil validasi ahli materi awal mendapatkan ratarata sebesar $73 \%$ dengan kategori valid. Dari hasil nilai rata-rata validasi ahli materi dan ahli media didapatkan nilai rata-rata sebesar 69\% dengan kategori valid. Selanjutnya video 
pembelajaran sains berbasis problem based leraning layak diujicobakan pada tahap one to one dan small group evaluation untuk melihat kepraktisan dari video pembelajaran sains berbasis problem based leraning.

Setelah dilakukan tahap expert review terhadap prototipe 1, selanjutnya peneliti melakukan tahap one to one evaluation yang bertujuan untuk melihat kepraktisan video pembelajaran sains berbasis problem based leraning dengan prototipe 1 yang telah divalidasi oleh ahli media dan ahli materi. Pada tahap ini melibatkan tiga anak dan mereka secara bersamaan melihat prototipe 1. Uji coba dilakukan dengan tujuan untuk melihat kesulitankesulitan yang mungkin terjadi selama proses pembelajaran menggunakan video pembelajaran sains berbasis problem based leraning. Nilai yang didapatkan dari observasi pada tiga anak. Tiga anak tesebut adalah NAK, DPW, DKS yang masing-masing anak mendapatkan rekapitulasi nilai $87 \%$, 91\%, dan $84 \%$ sehingga nilai rata-rata adalah $87 \%$ dan berada pada kategori sangat praktis yang ditunjukkan pada tabel 2 .

Tabel 2. Rekapitulasi Tahap One To One Evaluation

\begin{tabular}{ccc}
\hline No & Inisial & Rekapitulasi Nilai \\
\hline 1. & NAK & $87 \%$ \\
2. & DPW & $91 \%$ \\
3. & DKS & $84 \%$ \\
\hline \multicolumn{2}{c}{ Rata-Rata } & $\mathbf{8 7 \%}$ \\
Kategori & Sangat Praktis \\
\hline
\end{tabular}

Selanjutnya pada tahap smal group evaluation, pada tahap ini diujikan pada sembilan orang anak dengan menggunakan portotipe 2. Anak dibagi menjadi tiga kelompok yang terdiri dari tiga anak. Sembilan anak tersebut adalah NAK, DPW, DKS, SA, MA, ANN, BM, MAF, dan RS. Masing-masing mendapatkan rekapitulasi nilai 94\%, 97\%, 84\%, 87\%, 78\%, 84\%, 97\%, 91\%, dan $87 \%$ sehingga mendapatkan nilai rata-rata sebesar $89 \%$ dan berada pada kategori sangat praktis. Pada saat proses pelaksanaanya, peneliti berperan sebagai pendamping dalam proses pembelajaran menggunakan video aktivitas sains berbasis problem based leraning selama berlangsungnya kegiatan small group evalation. Hasil evaluasi pada tahap small group evaluation ditunjukkan pada tabel 3.

Tabel 4. Rekapitulasi Nilai Tahap small group evalation

\begin{tabular}{clc}
\hline No & Nama & Rekapitulasi Nilai \\
\hline 1. & NAK & $94 \%$ \\
2. & DPW & $97 \%$ \\
3. & DKS & $87 \%$ \\
4. & SA & $84 \%$ \\
5. & MA & $78 \%$ \\
6. & ANN & $84 \%$ \\
7. & BM & $97 \%$ \\
8. & MAF & $91 \%$ \\
9. & RS & $87 \%$ \\
\hline \multicolumn{2}{l}{ Rata-Rata } & $\mathbf{8 9} \%$ \\
\hline \multicolumn{2}{l}{ Kategori }
\end{tabular}

Peneliti menjelaskan tentang video pembelajaran sains berbasis problem based leraning dari kegiatan awal hingga akhir, serta percobaan apa saja yang akan dilakukan. Video pembelajaran sains berbasis problem based leraning dilakuan dengan cara anak memperhatikan 
video yang ada untuk mengetahui langkah-langkah apa saja yang akan dilakukan dalam percobaan sains, sehingga anak dapat memahami konsep sains dari kegiatan yang dilakukan.

Sains merupakan kombinasi dari keterampilan proses dan konten apa yang dipelajari anak (Jackman dikutip Yaswinda et al., 2018: 14). Pembelajaran sains pada anak usia dini memiliki tujuan untuk mengembangkan pemahaman dasar anak tentang pengetahuan dan keterampilan inkuiri (Saçkes, 2014). Pembelajaran sains pada anak usia dini harus dikenalkan dengan strategi yang tepat dan menyenangkan, sehingga nantinya anak akan lebih mudah memahami pembelajaran sains yang diajarkan (Utami et al., 2022). Menurut Wiedarti dikutip oleh Zahro et al., 2019: 122-123), strategi pembelajaran yang dapat digunakan dalam pembelajaran sains meliputi perencanaan, pelaksanaan, dan penilaian. Dalam perencanaan, guru sudah menyiapkan tujuan, materi, media, dan metode pembelajaran yang akan digunakan dalam penyampaian materi sains melalui literasi. Literasi yang digunakan pada pembelajaran ini yaitu literasi media. Morrison yang dikutip oleh (Poerwati et al., 2022) mengatakan bahwa anak sangat penting untuk diajarkan sains karena anak adalah tempatnya untuk bertanya tentang alam sekitar, sebagai literasi anak, anak juga dapat belajar lisan dan tertulis ketka mengeksplorasi sains, selain itu anak juga belajar mengamati keragaman hayati, sains juga mengajarkan anak untuk menghormati dan peduli dengan alam semesta, serta anak belajar menjadi ilmuwan dan belajar menyukai sains sejak dini. Menurut Aprinawati dalam Utami \& Andika (2021) mengatakan bahwa media adalah sesuatu yang dipergunakan dalam menyalurkan suatu pesan yang dapat merangsang pikiran, perasaan, perbuatan, minat serta perhatian siswa sehingga akan terjadinya proses belajar mengajar pada diri anak.

Lehsin, Pollock \& Reigeluth dikutip oleh Arsyad (2017: 36) mengklasifikasikan media ke dalam lima kelompok, yaitu: (1) media berbasis manusia, (2) media berbasis cetak, (3) media berbasis visual, (4) media berbasis audio-visual, (5) media berbasis komputer. Menurut Riyana (2019: 6), media video adalah media atau alat bantu yang menyajikan audio dan visual yang berisi pesan-pesan pembelajaran, baik yang berisi konsep, prinsip, prosedur, teori aplikasi pengetahuan untuk membantu pemahaman suatu materi pembelajaran. Media memberikan banyak manfaat dalam pembelajaran. Menurut Sudjana (2017: 2) manfaat media pengajaran dalam proses belajar siswa sebagai yaitu: a) motivasi belajar siswa dengan pembelajaran yang menarik. b) siswa dapat lebih memahami materi jika bahan pengajaran yang ada lebih memperjelas maknanya, dan memungkinkan siswa menguasai tujuan pengajaran yang lebih baik. c) lebih bervariasinya metode mengajar yang dilakukan gurua agar anak tidak mudah bosan.

Karakteristik dari media video dalam meningkatkan efektifitas dan efesiensi proses pembelajaran menurut Munadi yang dikutip oleh Hidayat (2021) adalah sebagai berikut, mengatasi jarak dan waktu; mampu menggambarkan peristiwa-peristiwa masa lalu secara realistis dalam waktu yang singkat; dapat membawa siswa berpetualang dari negara satu ke negara lainnya, dan dari masa yang satu ke masa yang lain; dapat diulang-ulang bila perlu untuk menambah kejelasan; pesan yang disampaikannya cepat dan mudah diingat; megembangkan pikiran dan pendapat para siswa; mengembangkan imajinasi; memperjelas hal-hal yang abstrak dan memberikan penjelasan yang lebih realistik.

Arifin (2019) menyatakan bahwa Problem Based Learning yang disebut PBL adalah salah satu model pembelajaran yang berpusat pada peserta didik dengan cara menghadapkan para peserta didik tersebut dengan berbagai masalah yang dihadapi dalam kehidupannya. Rusman (2017: 243) mengemukakan langkah-langkah model Problem Based Learning yang digunakan yaitu orientasi anak pada masalah, mengorganisasi anak untuk belajar, membimbing pengalaman individual atau kelompok, mengembangkan dan menyajikan hasil karya, dan menganalisis dan mengevaluasi proses pemecahan masalah. Sejalan dengan pendapat Jerzembek \& Murphy (2013) yang menyatakan bahwa problem based learning menggambarkan pembelajaran yang menggunakan masalah sebagai konteks bagi anak untuk belajar keterampilan pemecahan masalah dan memperoleh pengetahuan. Hasil penelitian Sugiyanto \& Ramang (2021) juga menyatakan bahwa problem based learning dapat menciptakan 
pembelajaran yang menyenangkan, membangun keterampilan berkomunikasi, berkolaborasi dan menerapkan pembelajaran yang dapat mendorong keaktifan anak untuk berpikir kritis, kreatif dan mampu memecahkan masalah. Selain itu, problem based learning juga terbukti efektif dalam meningkatkan prestasi akademik anak, termasuk pengetahuan, pengembangan konseptual, dan sikap (Hirshfield \& Koretsky, 2017).

\section{SIMPULAN}

Produk yang dikembangkan pada penelitian ini berupa video pembelajaran sains berbasis problem based learning dinyatakan valid berdasarkan hasil pengujian oleh ahli media dan ahli materi. Video pembelajaran sains berbasis problem based learning dinyatakan praktis berdasarkan pengujian one to one evaluation dan small group evaluation, sehingga dapat disimpulkan bahwa video pembelajaran sains berbasis problem based learning layak digunakan untuk anak usia dini. Saran yang dapat diberikan oleh peneliti kepada peneliti selanjutnya yaitu dapat mengembangkan video pembelajaran dengan muatan problem based learning dengan materi yang berbeda sesuai dengan kebutuhan anak usia dini.

\section{UCAPAN TERIMAKASIH}

Penulis mengucapkan terima kasih kepada semua pihak yang terlibat dalam penyelesaian penelitian ini. Selain itu, peneliti juga kepada Tim Jurnal Obsesi yang telah memberikan saran dan masukan untuk artikel ini sampai artikel ini dapat diterbitkan.

\section{DAFTAR PUSTAKA}

Aditian, Y., Moh, S., \& Ikman. (2015). Pengembangan media pembelajaran interaktif berbasis macromedia flash 8.0 pada materi bangun ruang di smp negeri 9 kendari. Jurnal Penelitian Pendidikan Matematika Volume 3 No. 2 Mei 2015, 1-16.

Arifin, S. (2019). Metode Problem Based Learning (Pbl) Dalam Peningkatan Pemahaman Fikih Kontemporer. Ta'lim: Jurnal Studi Pendidikan Islam, 2(1), 88-106.

Arsyad, A. (2017). Media Pembelajaran Pendidikan. Rajawali Press.

Cahyati, N., Syafdaningsih, S., \& Rukiyah, R. (2018). Pengembangan Media Interaktif Dalam Pengenalan Kata Bermakna Pada Anak. Cakrawala Dini: Jurnal Pendidikan Anak Usia Dini, 9(2), 160-170. https://doi.org/10.17509/cd.v9i2.11339

Dejonckheere, P. J. N., De Wit, N., Van de Keere, K., \& Vervaet, S. (2016). Exploring the classroom: Teaching science in early childhood. International Electronic Journal of Elementary Education, 8(4), 537-558. https://doi.org/10.12973/eu-jer.5.3.149

Dewi, A. C. (2012). Meningkatkan Kemampuan Sains Anak Usia Dini Melalui Pembelajaran Berbasis Ketrampilan Proses. Malih Peddas (Majalah Ilmiah Pendidikan Dasar), 1(2). https://doi.org/10.26877/malihpeddas.v1i2.301

Gross, C. M. (2012). 2012 J- Science Concepts Yng Chldrn Learn Thr Water Play. Dimentions of Early Childhood, 40(2), 3-12.

Hidayat, D. (2021). Pengaruh Media Pembelajaran Audiovisual Pada Masa Pandemi Covid-19 Terhadap.

Hirshfield, L., \& Koretsky, M. D. (2017). Gender and Participation in an Engineering ProblemBased Learning Environment The Interdisciplinary Journal of Problem-based Learning Special Issue On Competency Orientation in Problem-BasED Learning Gender and Participation in an Engineering Problem-Base. 12(1), 5-17. https://doi.org/10.7771/1541-5015.1651

Jerzembek, G., \& Murphy, S. (2013). A narrative review of problem-based learning with schoolaged children: Implementation and outcomes. Educational Review, 65(2), 206-218. https:// doi.org/10.1080/00131911.2012.659655

Moallem, M., Hung, W., \& Dabbagh, N. (2019). Understanding PBL : Historical and Theoretical Foundations Introduction. The Wiley Handbook of Problem-Based Learning, 1-2. https://doi.org/10.1002/9781119173243.part1 
Padilah, P., Utami, F., Sari Jaya, M. P., Sinaga, S. I., Novianti, R., \& Noverina, R. (2018). Sosialisasi Inovasi Media Pembelajaran Permainan Tunas Integritas Untuk Perkembangan Anak Usia Dini Di Paud Kasih Bunda Yuliani Kec. Ilir Barat I. Wahana Dedikasi : Jurnal PkM Ilmu Kependidikan, 1(2). https:// doi.org/10.31851/dedikasi.v1i2.2278

Poerwati, C. E., Cahaya, I. M. E., Made, N., \& Suryaningsih, A. (2022). Pengaruh Model Pembelajaran Problem Based Learning Berbasis Eksperimen Sederhana dalam Pengenalan Sains Anak Usia Dini. 6(3), 1472-1479. https://doi.org/10.31004/obsesi.v6i3.1233

Rerung, N., Sinon, I. L. ., \& Widyaningsih, S. W. (2017). Penerapan Model Pembelajaran Problem Based Learning (PBL) untuk Meningkatkan Hasil Belajar Peserta Didik SMA pada Materi Usaha dan Energi. Jurnal Ilmiah Pendidikan Fisika Al-Biruni, 6(1), 47-55. https://doi.org/10.24042/ipifalbiruni.v6i1.597

Riyana, C. (2019). Produksi Bahan Pembelajaran Berbasis Online. Univeritas Terbuka.

Rusman. (2017). Belajar dan Pembelajaran Berorientsi Standar Proses Pendidikan. Kencana.

Saçkes, M. (2014). How often do early childhood teachers teach science concepts? Determinants of the frequency of science teaching in kindergarten. European Early Childhood Education Research Journal, 22(2), 169-184. https:// doi.org/10.1080/1350293X.2012.704305

Seibert, S. A. (2021). Problem-based learning: A strategy to foster generation Z's critical thinking and perseverance. Teaching and Learning in Nursing, 16(1), 85-88. https:// doi.org/10.1016/j.teln.2020.09.002

Sudjana, N. (2017). Penialian Hasil Proses Belajar Mengajar. Rosdakarya.

Sugiyanto, \& Ramang. (2021). Model Pembelajaran Penerapan Problem Based Learning Pada Anak Usia Dini. Wiyatamandala, I(I), 86-95.

Sugiyono. (2019). Metode Penelitian Pendidikan: Pendekatan Kuantitatif, Kualitatif dan R\&D. CV Alfabeta.

Syafi'i, I., Sa'diyah, C., Wakhidah, E. W., \& Umah, F. M. (2020). Penerapan Video Pembelajaran Daring Anak Usia Dini Pada Masa Pandemi Covid-19. Al-Athfaal: Jurnal Ilmiah Pendidikan Anak Usia Dini, 3(2), 140-160. https://doi.org/10.24042/ajipaud.v3i2.7315

Trundle, K. C. (2015). The Inclusion of Science in Early Childhood Classrooms. In Research in Early Childhood Science Education (pp. 1-6). Springer, Dordrecht. https:// doi.org/10.1007/97894-017-9505-0_1

Utami, F. (2020). Pengaruh Metode Pembelajaran Outing Class terhadap Kecerdasan Naturalis Anak Usia 5-6 Tahun. Jurnal Obsesi: Jurnal Pendidikan Anak Usia Dini, 4(2), 551. https://doi.org/10.31004/obsesi.v4i2.314

Utami, F., \& Andika, W. D. (2021). Pengembangan Media Flashcard Berbasis Augmented Reality pada Materi Mengenal Binatang Laut. 5(2), 1718-1728. https://doi.org/10.31004/obsesi.v5i2.933

Utami, F., Rantina, M., \& Edi, R. (2022). Pengembangan Lembar Kerja Anak Menggunakan QR Code pada Materi Sains Anak Usia Dini. 6(3), 1976-1990. https://doi.org/10.31004/obsesi.v6i3.1882

Wulandari, A., \& Suparno, S. (2020). Pengaruh Model Problem Based Learning terhadap Kemampuan Karakter Kerjasama Anak Usia Dini. Jurnal Obsesi : Jurnal Pendidikan Anak Usia Dini, 4(2), 862. https://doi.org/10.31004/obsesi.v4i2.448

Yaqoob, N., Bibi, T., \& Mansoor, M. O. (2018). Early Childhood Learning Videos on YouTube: A Thematic Analysis of Viewer's Perceptions. Journal of Early Childhood Care and Education, 2, 35-50.

Yaswinda, Yulsyofriend, \& Farida Mayar. (2018). Pengembangan Bahan Pembelajaran Sains Berbasis Multisensori Ekologi Bagi Guru Paud Kecamatan Tilatang Kamang Kabupaten Agam. Yaa Bunayya : Jurnal Pendidikan Anak Usia Dini, 2(2), 13-22.

Zahro, I. F., Atika, A. R., \& Westhisi, S. M. (2019). Strategi Pembelajaran Literasi Sains Untuk Anak Usia Dini. Jurnal Ilmiah Potensia, 4(2), 121-130. https:/ / doi.org/10.33369/jip.4.2.121-130 